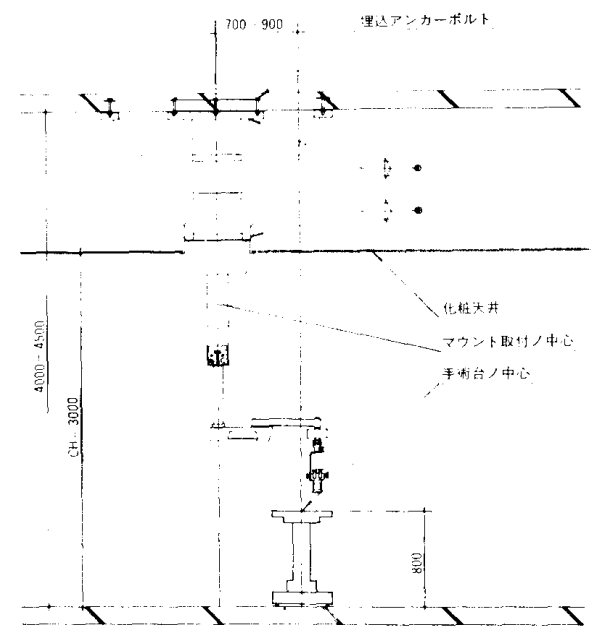

図2 取付立面図

が妥当である。1000 mm 以下だと作業空間が 不充分であり，また電源部の取付空間がなくな ってしまう。㭕を取りすぎると，架台が長く なり，振動の原因になる，振動防止のため，何本 ものフレ取めフレームを取付け权ばならなくな り，必要以上の空間を取りか数ない。この空閒 には，医療配管，空調多トなどが設置される ため，可能な限り寸法を大きく取る傾向はある。 建物設計段階で検討を要する部分である。

\section{3. 他の機器との位置関係}

四 3 は手術用顥微鏡が実際に取付的的た状 況で，無影灯との位置関係を示している．使用 上問題になるのは，手術用顕微鏡と無影灯のア 一ムが，互いに干渉し合うケースである、マイ クロサージャリー専用の手術窒では，マイクロ 使用時は，無影灯は使用しないため，問題にな

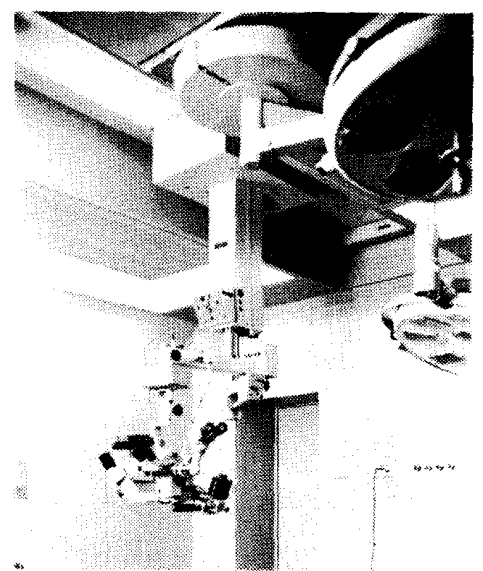

図 3 天井懸架式手術用顕微鏡

らないが，日本の場合，各科共通の部屋を使用 寸ることが多いため，しばしばトラブルの原因 になる。この他に医療ガスコラムおよびレント ゲン等の配置も事前に打合せ加必要で，できれ 代，プラスチックのモデルの手術室を作り，確 認寸るのが望ましい，思わ好問題を防ぐことが できるためである。

\section{4.おわりに}

上記では，使用される手術室の問題点を述べ て来たが，上階が器械室の場合，天井スラブの 振動も考慮せ齐ばならず，壁面を含めた環境で 検討をする必要がある。ここでは手術用顕微鏡 だけの立場から問題点を上げて見たが，それぞ れの立場からの検討も参考にサ就ならない。 今後も研究会を利用し，問題点を解消す心゙く検 討して行く必要性がある。

\title{
メ一カ一の立場から (III)
}

\section{1.はじめに}

手術室におけるX線設備は，そのほとんどが 整形外科領域における術中透視用のモビール式

（6インチII）X線テレビ装置が主体であった が近年高度医療の進展に伴い四肢以外の透視撮

\section{東芝メディカル(秋)}

秋山喜幸

影，あいはモビールタイプとの組合せにより 2 方向同時透視を可能にできる大容量のX線管 を保持した天井支持式C形アーム X線テレビ装 置や撮影専用支持装置を導入才る病院が増えて きた。 


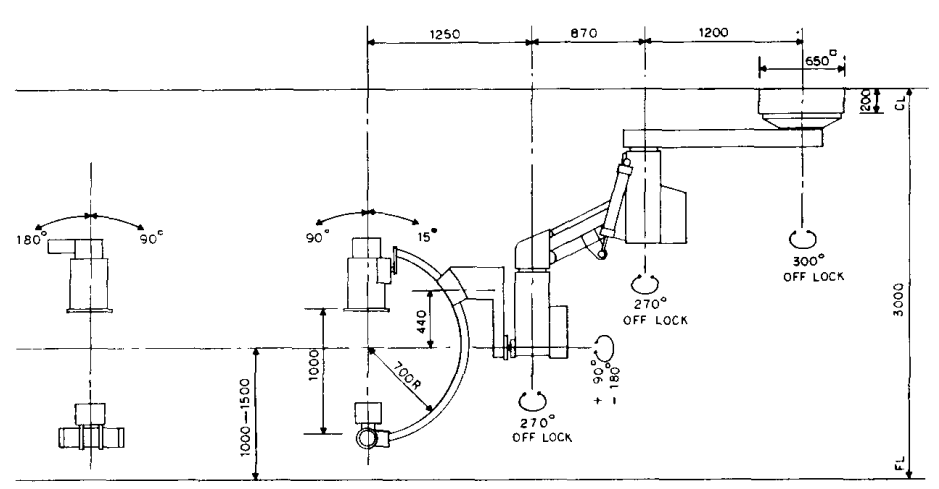

図 1ー1 天井支持式 $C$ 形アーム $\mathrm{X}$ 線テレビ装置

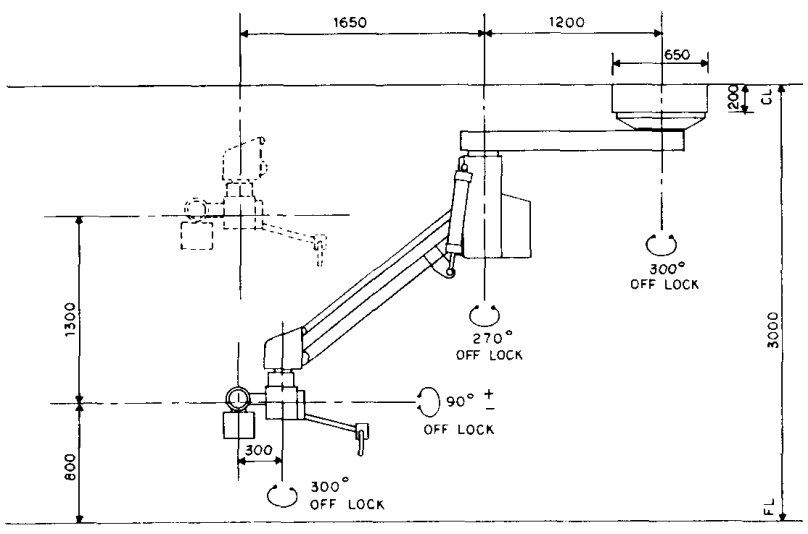

图 1-2 天井支持式 X線管支持装置

ここでは天井支持式X線装置を設備するうえ で考えられる諸問題を検討してみたい。

\section{2. 手術室のX線設備についての検討}

\section{[X線の防護]}

$\mathrm{X}$ 線手術室は診療用 $\mathrm{X}$ 線室と同じく，医療法 施行規則に基づく画壁面に対して，X線防護措 置が必要となる。またX線を発生させる場所と， 操作する場所は従事者の被曝を防止する上で別 にしなくて岒ならない, 即ち, X線操作室を設 けなくてはならないためである。

\section{〔耐荷重〕}

床面に設置される重量機器で特に問題なのは, 高圧発生器である機種によっても異なるが 350 $\mathrm{kg} \sim 1,500 \mathrm{~kg}$ で，設置床面積は $0.35 \mathrm{~m}^{2} \sim 0.65$ $\mathrm{m}^{2}$ 程度である。

天井面に設置されるものとしては，天井支持 アーム架台で装置重量は $450 \mathrm{~kg} \sim 550 \mathrm{~kg}$ 程度 であるが，支持アームが回転するため架台取付 ベースにはモーメント荷重が加わるので, 取付 ベースの固定についてはネジレやタワミ等が生 じないような補強工事を必要とする。

[天井有効高]
C形ア一ム支持装置は手術台の上下動に追従 可能なように約 $400 \mathrm{~mm}$ の上下ストロークの機 能を有することが条件となる。

また撮影支持装置については手術台からの上 方向の撮影距離 (FFD) $1 \mathrm{~m}$ をクリアさせるこ とでアーム架台の取付高は $\mathrm{CH}=2,800 \sim 3,000$ $\mathrm{mm}$ を必要とする(図 1-1，1-2 参照).

[電源設備]

$\mathrm{X}$ 線装置の 1 次側電源設備容量は2 次側の定 格負荷により決定されるが，単相X線の場合で は (R F - 125-500) で単相 $200 \mathrm{~V}, 50 \mathrm{KVA}$. 三相X線の場合では（TRF-150-1000）で三 相 $200 \mathrm{~V}, 100 \mathrm{KVA}$ の設備容量を必要とする. 接地に対しては, X線機器は第 3 種接地とし, $\mathrm{ME}$ 機器の第 1 種との等電位補護接地を充分検 討したうえで接地計画を行うものとする。

\section{3. 天井支持式 $\mathrm{C}$ 形アーム $\mathrm{X}$ 線テレビ装置 の仕様}

1) X線管焦点 I. I 入力面間距離 : $1 \mathrm{~m}$

2）Cアーム上下動：ストローク約 $40 \mathrm{~cm}$

3）べースを中心とするアームの回転範囲 $: 300$ 度

4）懸垂アームの回転範囲 : 300 度

5）Cアームの旋回：180 度

6） Cアーム取支柱を中心とする回転範囲 : 300 度

7）Cアームのスライド : +90 度， -25 度

8）最大回転範囲：約 $3,500 \mathrm{~mm}$

9）必要天井高 : 2,800 以上

10）イメージ・インテンシファイヤ

$$
\text { : } 6 \text { 〜 } 9 \text { インチ }
$$

11） X線管容器: 回転陽極 $\mathrm{X}$ 線管

12）バリェーションシステム 
。1 枚撮り用カセッテホルダー

。スポットカメラおよびシネカメラ取

付可能

13）電源： $100 \mathrm{~V} / 200 \mathrm{~V} \pm 10 \%$

$50 / 62 \mathrm{~Hz}$ 容量 $3 \mathrm{KVA}$

14）重量: 約 $550 \mathrm{~kg}$

\section{4. 天井支持式 X線管支持装置の仕様}

1）べースを中心とするアームの回転範囲 : 300 度

2）懸垂アームの回転範团：300 度

3）䀣垂ア一ム上下動：約 $160 \mathrm{~cm}$ (最大)

4） X線管支持アームの回転範囲：300 度

5） X線管の旋回 : 300 度

6）最大回転範囲 : $290 \mathrm{~cm}$

7）必要天井高 : 2, 800 以上

8） X線管容器：回転陽極 $\mathrm{X}$ 線管

9) 電源 : $100 \mathrm{~V} / 200 \mathrm{~V} \pm 10 \%$

$50 / 60 \mathrm{~Hz}$ 容量 $2 \mathrm{KVA}$

10）重量: $300 \mathrm{~kg}$

\section{5. $\mathrm{X}$ 線手術室の天井スペースの検討}

図 2-1 でX線手術室の天井に設置される機 器

1. CアームX線支持装置

2. X線管支持装置

3. 手術用照明灯（親子式）

4. 手術用照明灯抢よびX線テレビモニター

5. ME監視モニタ一支持装置

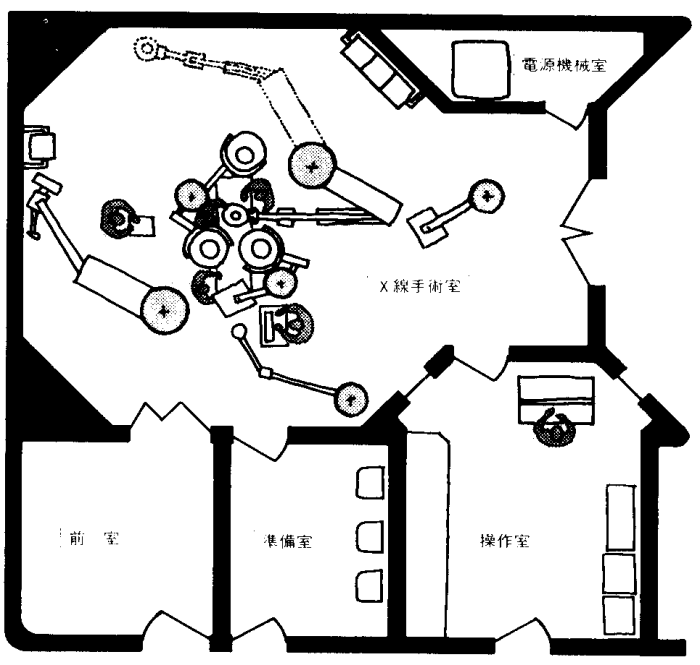

図 2-1

6. X線テレビモニターおよびビデオモニター

7. X線テレビモニター

8. 医療ガス，シーリング，ア一ム装置

このほかに考慮しておかねばならない機器は 顕微鏡シーリングアーム装置, 麻酔器シーリン グアーム装置等の天井利用も考えられる。また 室内照明や空調の吹出し孔や排気孔の位置関係 の検討も重要である。

$\mathrm{X}$ 線設備の手術室は天井設置の機器類が多く なるため，相互のアームの干渉を防ぎ，手術台 を中心にした術者の動線と天井設置機器との位 置関係を充分検討したうえで，機能的な天井ス ペース利用を考えたいものである。 